\title{
Changes in myometrial and placental 15-hydroxyprostaglandin dehydrogenase with ovine parturition: production of prostaglandin metabolites in vitro and in vivo
}

\author{
M. J. N. C. Keirse*, M. D. Mitchell and A. P. F. Flint $\dagger$ \\ Nuffield Department of Obstetrics and Gynaecology, University of Oxford, \\ John Radcliffe Hospital, Oxford OX3 9DU, U.K.
}

\begin{abstract}
Summary. 15-Hydroxyprostaglandin dehydrogenase (PGDH) was measured in vitro in myometrium and maternal cotyledons from 6 sheep and in fetal cotyledons from 3 sheep before and after parturition. Maternal cotyledons contained more PGDH than fetal cotyledons or myometrium. At parturition, PGDH activity decreased in myometrium but increased in fetal and maternal placental tissue. The enzymatic activity observed in vitro did not result in a large, consistent release of prostaglandin $F$ metabolites into the utero-ovarian vein in vivo, and such activity may have a strictly localized effect in ovine parturition.
\end{abstract}

\section{Introduction}

Much evidence has accumulated to implicate prostaglandins in the process of parturition in the sheep. Concentrations of prostaglandin (PG) F-2 $\alpha$ rise in uterine venous plasma and in several uterine tissues during lambing (Liggins \& Grieves, 1971; Thorburn, Nicol, Bassett, Shutt \& Cox, 1972). Uterine activity can be stimulated by chronic or acute infusion of PGF-2 $\alpha$ (Liggins, Fairclough, Grieves, Kendall \& Knox, 1973; Mitchell, Flint \& Turnbull, 1976a) and inhibited by meclofenamic acid, a PG synthetase inhibitor (unpublished). These elevated PG concentrations could result from increased synthesis or decreased catabolism. High rates of PGF catabolism have been demonstrated in vitro in some uterine tissues from pregnant sheep (Keirse, Hicks \& Turnbull, 1976a), but it is not known whether the catabolic activity changes with the onset of parturition. To assess such changes we have measured rates of PG catabolism in vitro before and after parturition, and examined arterio-venous differences in the concentrations of major metabolites of PGF-2 $\alpha$.

\section{Materials and Methods}

Cotyledons and myometrium were obtained at hysterotomy from 6 ewes between 120 and 140 days of gestation. Parturition occurred spontaneously or was induced by intrafetal administration of dexamethasone (Oradexon: Organon, Morden: $1 \mathrm{mg} / 24 \mathrm{~h}$ ) or synthetic ACTH (Synacthen: Ciba, Horsham: $0.1 \mathrm{mg} / 24 \mathrm{~h}$ ) frorh the 5 th day after operation. All lambs were born alive. Within $15 \mathrm{~min}$ of lambing the ewes were killed by intravenous administration of thiopentone sodium (Pentothal: Abbott, Kent) and further samples of cotyledons and myometrium were again obtained. Cotyledons were separated manually into fetal and maternal components. Freshly obtained myometrium and maternal cotyledons from all 6 ewes and fetal cotyledons from 3 of them were used for determination of 15-hydroxyprostaglandin dehydrogenase (PGDH). Blood samples for PG measurements were obtained by means of utero-ovarian venous and carotid or aortic catheters (the latter inserted via the femoral artery) from 3 of the 6 ewes described above and a further 2 animals, all between 120 and 140 days of gestation. Venous and arterial samples obtained within $3 \mathrm{~min}$ of each other were immediately centrifuged to obtain plasma which was stored at $-20^{\circ} \mathrm{C}$.

\footnotetext{
* Present address: Department of Obstetrics and Gynaecology, University of Leiden, University Hospital, Rijnsburgerweg 10, Leiden, The Netherlands.

† Present address: A.R.C. Institute of Animal Physiology, Babraham, Cambridge CB2 4AT, U.K.
} 
15-Hydroxyprostaglandin dehydrogenase was measured as described by Keirse et al. (1976b). Weighed portions of tissue were homogenized in 7 vols $0.1 \mathrm{M}$-potassium phosphate containing 20

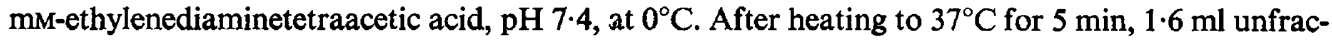
tionated homogenate was added to $0.4 \mathrm{ml}$ medium containing $0.5 \mathrm{~mm}-\left[9-{ }^{3} \mathrm{H}\right] \mathrm{PGF}-2 \alpha$ (sp.act. 25 $\mathrm{Ci} / \mathrm{mol}$, prepared from Prostin F-2 $\alpha$ (Upjohn, Crawley) and $\left[9-{ }^{3} \mathrm{H}\right] \mathrm{PGF}-2 \alpha$, sp.act. $15 \mathrm{Ci} / \mathrm{mmol}$ : Radiochemical Centre, Amersham) and $10 \mathrm{~mm}$-nicotinamide adenine dinucleotide $\left(\mathrm{NAD}^{+}\right)$. Samples $(0.2 \mathrm{ml})$ removed at $0,3,6,9,12,18,24,36,48$ and $72 \mathrm{~min}$ were added to $0.5 \mathrm{ml}$ ethanol containing formic acid $(0 \cdot 5 \%, \mathrm{v} / \mathrm{v})$. Prostaglandins were extracted twice with $5 \mathrm{ml}$ chloroform and the extracts subjected to thin-layer chromatography in chloroform:methanol:acetic acid:water $(90: 8: 1: 0 \cdot 8$, by vol.) to separate PGF- $2 \alpha$ from its metabolites. The percentage of PGF- $2 \alpha$ metabolized, calculated on the basis of ${ }^{3} \mathrm{H}$ recovered in the PGF- $2 \alpha$ and combined metabolite fractions, was plotted against incubation time. PGDH activity was obtained by linear regression analysis of all points which corresponded to the initial reaction velocity; at least 5 time points were used and all $r$ values were $>0.97$. Duplicate homogenization and incubation at tissue concentrations ranging from 50-200 $\mathrm{mg} / \mathrm{ml}$ gave values which were within $10 \%$ of the mean $(n=10)$.

Plasma levels of PG metabolites were measured by radioimmunoassay. The assay for 13,14dihydro-15-keto-PGF-2 $\alpha$ (DHKF) has been described previously (Mitchell et al., 1976b). Similar procedures were used to assay 15-keto-PGF- $2 \alpha(\mathrm{KF})$ and 13,14-dihydro-PGF-2 $\alpha$ (DHF); the antibodies were raised in rabbits against antigens prepared by conjugating these compounds with bovine serum albumin (Caldwell, Burstein, Brock \& Speroff, 1971). Tritiated metabolites were made by the method used by Mitchell et al. (1976b) to prepare [ $\left.{ }^{3} \mathrm{H}\right] \mathrm{DHKF}$.

\section{Results}

The results of PGDH determinations, expressed in ng PGF-2 $\alpha$ metabolized/g tissue (wet wt)/min are shown in Table 1. Although PGDH activity varied considerably between individual sheep, the maternal cotyledons consistently contained higher PGDH concentrations than fetal cotyledons or myometrium. These findings confirm those made previously in experiments in which the enzyme was not measured at $V_{\max }$ (Keirse $e t$ al., 1976a). In all ewes, the PGDH activity changed markedly and in a consistent manner with parturition, increasing in the maternal and fetal cotyledons and decreasing in myometrium (Table 1).

To assess whether large amounts of PGF- $2 \alpha$ are metabolized by the pregnant uterus in vivo arterio-venous concentration gradients across the uterus for endogenous KF, DHF and DHKF were

Table 1. 15-Hydroxyprostaglandin dehydrogenase activity (expressed as ng PGF-2 $\alpha$ metabolized/g wet tissue/min) in myometrium, maternal and fetal cotyledons from sheep before (B) and after (A) parturition

\begin{tabular}{|c|c|c|c|c|c|c|c|c|c|c|}
\hline \multirow[b]{2}{*}{ Animal } & \multirow{2}{*}{$\begin{array}{l}\text { Gestational } \\
\text { age at } \\
\text { operation } \\
\text { (days) }\end{array}$} & \multicolumn{3}{|c|}{ Myometrium } & \multicolumn{3}{|c|}{ Maternal cotyledon } & \multicolumn{3}{|c|}{ Fetal cotyledon } \\
\hline & & B & $\mathbf{A}$ & $A: B$ & B & $\mathbf{A}$ & $A: B$ & B & $\mathbf{A}$ & A:B \\
\hline 1 & 140 & 3292 & 1487 & 0.45 & 6195 & 9558 & 1.54 & N.D. & N.D. & - \\
\hline 2 & 135 & 531 & 389 & 0.73 & 1770 & 3292 & 1.86 & N.D. & N.D. & $\ldots$ \\
\hline 3 & 125 & 1699 & 212 & $0 \cdot 12$ & 3257 & 7009 & $2 \cdot 15$ & N.D. & N.D. & - \\
\hline 4 & 125 & 956 & 283 & $0 \cdot 30$ & 2513 & 5062 & 2.01 & 1558 & 5089 & 3.27 \\
\hline 5 & 120 & 1451 & 637 & 0.44 & 3646 & 6619 & 1.82 & 2726 & 5735 & $2 \cdot 10$ \\
\hline 6 & 122 & 2973 & 2124 & 0.71 & 4000 & 7823 & 1.96 & 885 & 1097 & $1 \cdot 24$ \\
\hline \multicolumn{2}{|l|}{$\begin{array}{l}\text { Mean } \\
\quad \pm \text { S.E.M. }\end{array}$} & $\begin{array}{r}1817 \\
\pm 449\end{array}$ & $\begin{array}{r}855 \\
+317\end{array}$ & $\begin{array}{r}0.48 \\
\pm 0.09\end{array}$ & $\begin{array}{r}3563 \\
\pm 620\end{array}$ & $\begin{array}{r}6561 \\
\pm 889\end{array}$ & $\begin{array}{r}1.89 \\
\pm 0.08\end{array}$ & \multicolumn{3}{|c|}{$\begin{array}{rr}1723 \quad 3977 \quad 2.20 \\
\pm 538 \pm 1452 \pm 0.59\end{array}$} \\
\hline \multicolumn{2}{|c|}{$\begin{array}{l}\text { Statistical difference } \\
\text { by two-tailed } t \text { test }\end{array}$} & \multicolumn{3}{|c|}{$P<0.005$} & \multicolumn{3}{|c|}{$P<0.001$} & \multicolumn{3}{|c|}{$P>0.05$} \\
\hline
\end{tabular}


determined in 5 sheep before and during parturition. Levels of KF and DHF were low in arterial and venous samples during parturition: $\mathrm{KF},<0.3 \mathrm{ng} / \mathrm{ml}, \mathrm{DHF},<0.05 \mathrm{ng} / \mathrm{ml}$. There was no arteriovenous difference for either metabolite before or during lambing. The results of the DHKF measurements are given in Table 2. In 2 of the 5 animals there was no significant arterio-venous difference, despite utero-ovarian venous PGF levels being elevated at birth; in the other 3 animals a small but significant concentration gradient was observed.

Table 2. Plasma concentrations (ng/ml) of 13,14-dihydro-15-keto-PGF-2 $\alpha$ during pregnancy in the sheep

\begin{tabular}{|c|c|c|c|c|c|c|}
\hline \multirow[b]{2}{*}{ Animal } & \multirow{2}{*}{$\begin{array}{l}\text { No. of paired } \\
\text { arterial and } \\
\text { venous samples }\end{array}$} & \multicolumn{2}{|c|}{$\begin{array}{c}\text { Conc. of 13,14-dihydro-15-keto-PGF-2 } \alpha \\
\text { (range of values) }\end{array}$} & \multirow{2}{*}{$\begin{array}{c}\text { Utero-ovarian } \\
\text { venous:arterial } \\
\text { (mean } \pm \text { S.E.M.) }\end{array}$} & \multicolumn{2}{|c|}{$\begin{array}{l}\text { Statistical difference } \\
\text { by one-tailed } t \text { test }\end{array}$} \\
\hline & & Aortic or carotid & Utero-ovarian venous & & $t$ & $P$ \\
\hline 3 & 6 & $5 \cdot 19-35 \cdot 41$ & $4 \cdot 84-36 \cdot 10$ & $1.04 \pm 0.046$ & 1.04 & N.S. \\
\hline 4 & 5 & $3 \cdot 17-5 \cdot 05$ & $4 \cdot 92-6 \cdot 32$ & $1.44 \pm 0.052$ & $7 \cdot 33$ & $<0.001$ \\
\hline 5 & 17 & $1 \cdot 18-10 \cdot 76$ & $1 \cdot 42-13 \cdot 84$ & $1.43 \pm 0.073$ & $5 \cdot 38$ & $<0.001$ \\
\hline 7 & 12 & $0 \cdot 88-16.40$ & $0 \cdot 76-12 \cdot 70$ & $1.32 \pm 0.219$ & $1 \cdot 39$ & N.S. \\
\hline 8 & 6 & $2 \cdot 67-8.50$ & $7 \cdot 45-18 \cdot 68$ & $2.67 \pm 0.424$ & 3.63 & $<0.001$ \\
\hline
\end{tabular}

\section{Discussion}

The lack of any consistent, large arterio-venous difference across the uterus for the PG metabolites measured may be due to several factors. It is possible that inappropriate metabolites were examined in the present study. This seems unlikely, however, because KF and DHKF together account for over $95 \%$ of the PGF metabolites formed in vitro (Keirse et al., 1976a). Secondly, it appears possible that a large proportion of the PGF-2 $\alpha$ produced during parturition is not accessible to the catabolic enzymes. Furthermore, if PGF-2 $\alpha$ were homogeneously distributed in an assumed intracellular water space of $300-400 \mu 1 / g$ wet tissue and readily available to the enzymes, the endogenous concentration in the maternal cotyledon during parturition (150-500 ng PGF-2 $\alpha / \mathrm{g}$; Liggins \& Grieves, 1971) would be low in comparison to the $K_{m}$ of PGDH for PGF-2 $\alpha$ (1-2 $\mu \mathrm{M}$ compared with a $K_{m}$ of 20-60 $\mathrm{M}$ for human placental PGDH; see Hansen, 1976). Whatever the reason may be, the net output of the PGF metabolites from the pregnant uterus in vivo is rather small, particularly when compared to that of PGF.

We have previously drawn attention to differences between ovine and human uterine tissues in the localization of PGDH (Keirse et al., 1975) and it now appears that there may also be quantitative differences in PGDH between these species. The highest PGDH activities observed in the present study were at least 10-fold lower than those present in the human placenta, in which PGDH activities, measured in a similar way, were $207 \pm 18$ (S.E.M., $n=44$ ) nmol PGF-2 $\alpha / \mathrm{g}$ wet tissue/min (Keirse $e t$ al., 1976b). The increase in PGDH activity in fetal and maternal cotyledons after birth may result from a need to protect the fetus against the high concentrations of PGF known to be associated with ovine parturition. Liggins \& Grieves (1971) have shown that, after induction of parturition, concentrations of PGF-2 $\alpha$ increase first in maternal cotyledons and later in myometrium and they have suggested that PGF-2 $\alpha$ originates mainly in the maternal cotyledons and then reaches the myometrium. The decrease in myometrial PGDH activity with parturition, causing lower catabolism, could contribute to the higher accumulation of PGF- $2 \alpha$ in myometrium during lambing. Together with the increase in placental PGDH activity this decrease in myometrial PGDH activity could represent a redistribution of $P G$ metabolism, which even without causing arterio-venous differences in the concentration of the major metabolites of PGF- $2 \alpha$, may be of importance in ovine parturition.

We thank Mrs B. R. Hicks for expert technical assistance; Professor A. C. Turnbull for his interest; Professor G. S. Dawes for use of the animal facilities in the Nuffield Institute for Medical Research; and Dr T. Kirton (Upjohn Co., Kalamazoo) for the PG standards. M.D.M. was supported by an M,R.C. scholarship and the work was financed by M.R.C. Programme Grant G971/809/C. 


\section{References}

Caldwell, B.V., Burstein, S., Brock, W.A. \& SPERoF, L. (1971) Radioimmunoassay of the F prostaglandins. J. clin. Endocr. Metab. 33, 171175.

Keirse, M.J.N.C., Hicks, B.R. \& TuRnbull, A.C. (1975) Comparison of intra-uterine metabolism of prostaglandin $F_{2 \alpha}$ in ovine and human pregnancy. J. Endocr. 67, 24P-25P.

KeIRSe, M.J.N.C., Hicks, B.R. \& TuRnbUll, A.C. (1976a) Metabolism of prostaglandin F-2 $\alpha$ in fetal and maternal cotyledons of sheep. J. Reprod. Fert. 46, 417-420.

KeIrSe, M.J.N.C., Hicks, B.R. \& Turnbull, A.C. (1976b) Prostaglandin dehydrogenase in the placenta before and after the onset of labour. Br. J. Obstet. Gynaec. 83, 152-155.

HANSEN, H.S. (1976) 15-Hydroxyprostaglandin dehydrogenase. A review. Prostaglandins 12, 647-679.

Liggins, G.C. \& Grieves, S. (1971) Possible role for prostaglandin $F_{2 \alpha}$ in parturition in sheep. Nature, Lond. 232, 629-631.

Liggins, G.C., Fairclough, R.J., Grieves, S.A., KENDALL, J.Z. \& KNOX, B.S. (1973) The mechanism of initiation of parturition in the ewes. Recent Prog. Horm. Res. 29, 111-159.

Mitchell, M.D., Flint, A.P.F. \& Turnbull, A.C. (1976a) Stimulation of uterine activity by administration of prostaglandin F-2 $\alpha$ during pregnancy in sheep. J. Reprod. Fert. 48, 189-190.

Mrtchell, M.D., Flint, A.P.F. \& TuRnbull, A.C. (1976b) Plasma concentrations of 13,14-dihydro-15keto-prostaglandin $F$ during pregnancy in sheep. Prostaglandins 11, 319-329.

ThorburN, G.D., Nicol, D.H., Bassetr, J.M., ShuTT, D.A. \& Cox, R.I. (1972) Parturition in the goat and sheep: changes in corticosteroids, progesterone, oestrogens and prostaglandin F. J. Reprod. Fert., Suppl. 16, 61-84.

Received 28 February 1977 